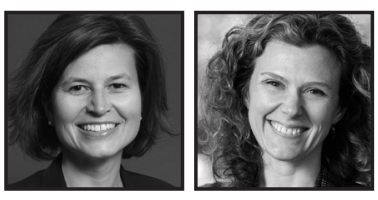

\title{
Sharing the Expertise: Middle School Girls and Community Members as Solution and Communication Partners ${ }^{1}$
}

\author{
Sara Hagenah, Boise State University \\ Jessica Thompson, University of Washington
}

\begin{abstract}
The documentary film Hicklin Lake: A Hopeful Future shows how middle school girls took on the roles of expert solution designers and communicators while partnering with multiple community members in an afterschool science club. Working towards justice for the future of a local toxic lake, the community members and girls co-investigated the complex story behind the lake's toxicity and needed actions to clean it up for future generations. This film is one product of a mutually beneficial experience between middle school girls and the community, where all learned about an unnatural problem that has natural solutions.
\end{abstract}

We, the Seattle Super STARS, hope that future generations of all animals can enjoy and be safe in and around Hicklin Lake. We also hope that people could start to think about making changes in other lakes from what we have learned from Hicklin Lake. We are one group, we can't fix the whole world, so we are starting with the Hicklin Lake. (film excerpt, 2014)

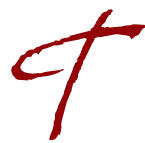

here are limited examples of how youth can interact with community members to learn about local scientific issues and take action together to make changes in the communities they live in. With the lack of examples, how community members can be included as both teaching and learning collaborators in formal and informal science spaces continues on a trial-and-error 
case-by-case basis. Both in and out-of-school spaces could benefit from further examples of how youth can meaningfully interact with community members to work towards change in their local communities.

In this paper, we describe a collaborative experience between middle school youth and community members as they collaborated in an afterschool science program around a local scientific issue that resulted in the production and sharing of a documentary film, Hicklin Lake: A Hopeful Future. Before continuing to read this manuscript, we recommend that readers first watch the documentary film: https://vimeo.com/92776664. Serving as a complementary manuscript to the documentary film, we provide an overview of community-based literature, then describe how middle school youth came to work with community members to co-develop solutions, next we describe how the youth took on the role of expert communicators, and finally we end with ideas around mutual and expansive learning across communities.

\section{Community-Based Science}

Drawing on ideas found in community-based literature, our study aims to further explore what it means for youth and community members to use science knowledge to engage collaboratively in transformative action in one's local community. Community-based literature provides evidence on how youth can connect with community members around projects, how youth can interact in and with local communities to make needed changes around local issues, and how community members can influence curricular design decisions (Bang et al., 2014; Bang \& Medin, 2010; Bouillion \& Gomez, 2001; Levine Rose \& Calabrese Barton, 2012; Medin \& Bang, 2014).

Youth and community members both bring valuable resources and funds of knowledge that are needed to take action in local communities. Bouillion and Gomez (2001) describe how a fifth grade classroom worked with community members to organize the cleaning up of a local riverbank. Through the shared interest in a clean river, low river pollution, and green space for the community, the fifth grade students were able to study a phenomenon and learn about the community they lived in. Levine Rose and Calabrese Barton (2012) discuss how youth draw on their own and community funds of knowledge as resources to make sense of local green energy technology issues and use this knowledge to take action in their community. 
Focusing on ways of knowing and community practices, Bang and colleagues worked with indigenous communities to develop community-based ways of knowing to deepen students' understandings and connections with indigenous ways of knowing by designing community-based curricula (Bang et al., 2014; Bang \& Medin, 2010; Medin \& Bang, 2014). In these studies, there was an increase in learning, interest, and efficacy in science when these students connected their own and community funds of knowledge with ideas on how to take action with and in their communities.

Aligned with evidence found in community-based literature, the afterschool program in this study was designed to attend to and be responsive to ideas and resources available from multiple stakeholders including community members, teachers, and students. We intend to add a descriptive example of how community and youth can be linked through learning and working together to provide both solutions and new communication methods with the extended community. Employing a design-based approach where community members are valued as teaching and learning collaborators (Penuel \& Fishman, 2012; Penuel, Fishman, Cheng, \& Sabelli, 2011), this study focused on the following research question: How do middle school girls and community members collaborate in an afterschool science club to communicate the explanation behind a local issue and potential solutions to the extended community?

\section{Solution Partners: Finding a Natural Solution to an Unnatural Problem}

Across one academic school year, 19 middle school girls collaborated with multiple community members and science teachers to use science knowledge to take action in their community. The girls were part of an afterschool science club, Students Tackling Authentic and Relevant Science (STARS), where middle school girls came to do science and produce a documentary film about how they decided to use their science knowledge and take action towards justice for a local issue in their community that they cared deeply about. The girls were puzzled by the toxicity of a lake, Hicklin Lake, which was located right outside their middle school. Hicklin Lake had excess nutrients in the water resulting in toxic cyanobacteria blooms in the warm summer months. The present-day lake condition stood in stark contrast to the stories told to the girls about what Hicklin Lake used to be like for family and community members. Grandparents would tell stories of jumping in the lake after school and environmental stewards shared how it used to be a gathering place 
for families on weekends to fish and have picnics. These stories differed from the present-day uses of Hicklin Lake so greatly, that the girls decided to take action to work towards a cleaner future Hicklin Lake. The girls wondered how the current condition came to be and why it was taking so long to clean up the lake. They wondered how the extreme condition of the lake could be communicated clearly to community members of all ages. They wondered how they could take action towards a better future for Hicklin Lake.

Taking action towards Hicklin Lake's future was not a task that the girls could take on themselves. Online resources provided disjointed information on what was done in the past to clean up Hicklin Lake, with most recent actions including the installation of floating islands that grew plants with roots that dangle in the water to take up excess nutrients. Understanding why the lake was the home of toxin-producing cyanobacteria was difficult, as there existed no clear pathway of what caused the current condition of the lake. Furthermore, accessing information about how the local community was informed about the toxicity was difficult to find beyond the few signs posted around the lake itself. All of these nonintersecting searches for information inspired the girls to construct their own model of this unnatural problem and develop natural solutions they could share with the community. By constructing a model of why the lake was toxic in warm summer months and contained little to no life, they could hypothesize natural solutions so that future generations of wild animals and humans could once again enjoy Hicklin Lake. In order to develop a deep understanding of the biochemical explanation behind Hicklin Lake's toxicity and consider viable solutions, the girls reached out to multiple community experts, community members who were professionals in their field or community role, to act as co-teachers and co-learners.

Multiple community members were keenly interested in working with the girls to take action towards cleaner lake water and communicating with the community about the lake. Previous cleanup efforts and community recognition events had taken place in the past, but the science behind why the lake was currently toxic and next steps towards its future were still in dire need of having collective community groups think and work together. The girls and afterschool teachers initially contacted the county limnologist to inquire about who would be willing to learn and take action with them. This initial contact had a domino effect, as the limnologist then brought forth numerous other community experts who each had a stake in the future of Hicklin Lake: ecological restoration scientists, community environmental stewards, watershed scientists, the park manager, local newspapers, and a park community coalition group that focused on safe community interactions in the 
park surrounding the lake. The afterschool group's interest in Hicklin Lake was welcomed by all and led to a multi-person collaborative framework to learn about and develop solutions to work towards a cleaner future for Hicklin Lake.

Viewing the STARS group as a source of hope for Hicklin Lake's future, community experts attended afterschool meetings and worked with the girls to clarify the biochemical story behind its toxicity and what actions were needed to help inform the community. Each community collaborator was key in the process of co-learning about the complex story behind why the cyanobacteria blooms persisted. Multiple resources about the local watershed and the importance of acting on cleaning up Hicklin Lake were shared between the community members and the girls. As the girls developed solutions they would present them to community members, who in return offered feedback and insights on the benefits and limitations of each solution design.

\section{Communication Partners: Informing the Extended Community}

Working towards justice for the future of Hicklin Lake and its surrounding community, the girls decided that they would focus on the future of the lake so it could be enjoyed in future generations by organisms of all kinds. Hearing stories about Hicklin Lake's rich past and its place in the community, the girls envisioned a future where it could be enjoyed again and not feared for its toxicity. Questions lingered as they dug into the explanation behind the lake's current state around what solutions would be the most beneficial for the community. Should the lake be filled up with dirt? Should a permanent fence be placed around the lake to ensure that no humans or animals interacted with toxic water? Or should they design natural solutions, such as a bioswale (a manmade wetland), to make it a safe place again for future generations? As these questions arose, the girls continuously consulted community members to ask about the viability of the proposed solutions. Community experts offered insight on how the impacts of proposed solutions could be maximized and provided a realistic view on items such as the expense and impact on Hicklin Lake's future. Community experts offered alternative solutions for the girls to consider, providing evidence of what they had found to work and not work in past cleanup efforts. 
The STARS girls were focused on what it meant to take action with knowledge and how this knowledge could affect future generations of humans and wildlife. They believed from the beginning that they could use their knowledge of science to take action on Hicklin Lake by posing natural solutions with community members and for the community to hear about. Consideration of how to communicate with the greater community included multiple conversations with community members over time. With the recommendation of the county limnologist and the park manager, the girls decided to communicate in two separate ways. One action they undertook was engineering and installing a set of nature walking tour signs around the lake so community members of all ages could have access to updated information about the toxic lake. This form of communication provided access for all community members to read updated information about the complex situation and potential solutions for Hicklin Lake.

The other communication action was the co-production of the documentary film, Hicklin Lake: A Hopeful Future, with Tara Champion, a conservation photographer and videographer. Youth production of documentary films is one way that youth can engage in multimodal learning (Toohey et al., 2015). Multimodal learning means that youth express themselves beyond oral language by expressing themselves through other means such as gestures and interactions. Furthermore, film production is a method of production pedagogy where students are positioned as creative knowledge sharers with larger audiences (Toohey \& Dagenais, 2015). An example of communicating youth and community engagement through film is in Stille's (2012; 2013) study of the interactions among youth, community members, and families as they shared cultural and linguistic resources to work on a school garden in a neglected school courtyard. As the collective group worked together, community members were able to share their knowledge of agricultural practices and connections between ways of living a more agricultural life were compared with their present way of living in high-rise apartments. The students in Stille's study produced a film as a result of this activity, a multimodal production of their interactions together in their garden space. Similar to the activity in the school garden space, the afterschool space in STARS drew upon multiple resources and areas of expertise for the students to learn from and ultimately share with the community in the form of a documentary film.

Film production occurred on a weekly basis after each STARS meeting. In each production meeting, the girls would collaborate and unpack the key learning that occurred with community experts and what was necessary to communicate with the greater community. While the community experts were not the key actresses in the documentary film, the scripts that the girls narrated and the actions that 
they undertook were the result of multiple interactions with the community members. Script writing included telling the story behind the lake's toxicity in both English and in some of the girls' primary languages. At the end of the film, some girls chose to narrate their personal journeys in STARS in a language of their choice, with many choosing their primary language, as they knew their family members who spoke their primary language would be watching the film. The stopgap animation was produced to provide a visual of the unobservable components of why the cyanobacteria bloomed in warm summer months. In the production of the stopgap animation film sections, the girls collectively worked together to move the felt pieces in between each captured picture and shared both life- and STARS-related stories with each other. In the film, the girls were the experts as they shared what they had co-learned with multiple community members. The girls decided to host a community-wide film showing where all community members were invited to attend and have a chance to ask questions about Hicklin Lake. At the showing, the nearly 100-member audience was filled with families, friends, teachers, administrators, local university faculty and personnel, the community members that collaborated with the girls, and neighbors that lived near Hicklin Lake.

\section{Mutual and Expansive Learning Across the Community}

Learning in STARS extended beyond the afterschool space and moved into the larger community in the form of the film and nature walking tour signs. Community experts and members learned about youth's desire to make Hicklin Lake a safe space for organisms of all kinds and the youth learned that solving such a complex problem required multiple steps to be taken place over time, with these steps relying upon multiple collaborative efforts to come to fruition. This documentary film is the result of learning that continually expanded across boundaries of the afterschool space into the collaborative circle of stakeholders who cared deeply about making an impact on the future of the lake. The film is a result of shared expertise, where community experts were not the only communicators of Hicklin Lake's conditions and needed solutions as the girls had acquired this role, too, through their experiences with the community experts. This mutual learning did not stop after the production of the film, but rather continued to expand in the following year when the county watershed scientists called upon the same afterschool group to develop public service announcements that could reach audiences of all ages across the community. 
Mimicking how scientists and the public engage in scientific issues (Levine Rose \& Calabrese Barton, 2012), this paper and documentary film add to the current body of literature by providing an in-depth description of how middle school youth collaborated with community experts to become expert solution designers and communicators with the extended community. Hicklin Lake: A Hopeful Future provides evidence of the impact that can come from sustained interactions between those in an educational space and community members with various backgrounds. It was through the common goal of cleaning up Hicklin Lake for future generations, that progress towards justice for an environmental issue that affected an entire community was able to happen. Moving beyond making connections with community and having community members help co-design learning spaces (Bang et al., 2014; Bang \& Medin, 2010; Bouillion \& Gomez, 2001; Levine Rose \& Calabrese Barton, 2012; Medin \& Bang, 2014), the close collaboration with community experts shifted youth into expert roles where they were the communicators of needed change. If we aim to help youth see how issues that surround them require collaborative groups to work towards solutions and develop new ways of communicating with others, future research needs to continue to provide descriptive examples of how youth can learn from and with community members to take action on meaningful issues they care about in their communities. These examples can then be taken up by both practitioners and researchers in formal and informal science learning spaces to make progress towards collaborative community-youth groups making changes together in educational settings.

\section{Note}

1. This research was supported by a grant from the National Science Foundation (DRL-1114481). The views expressed here are those of the authors. We are grateful for Tara Champion, a conservation photographer and videographer, and the girls in STARS who co-produced the film Hicklin Lake: A Hopeful Future. We are grateful for feedback from our close colleagues, from the editor of the journal, and from an anonymous reviewer. 


\section{References}

Bang, M., Curley, L., Kessel, A., Marin, A., Suzokovich III, E., \& Strack, G. (2014). Muskrat theories, tobacco in the streets, and living Chicago as indigenous land. Environmental Education Research, 20(1), 37-55.

Bang, M., \& Medin, D. (2010). Cultural processes in science education: Supporting the navigation of multiple epistemologies. Science Education, 94(6), 1008-1026.

Bouillion, L. M., \& Gomez, L. M. (2001). Connecting school and community with science learning: Real world problems and school-community partnerships as contextual scaffolds. Journal of Research in Science Teaching, 38(8), 878-898.

Levine Rose, S. L., \& Calabrese Barton, A. (2012). Should Great Lakes City build a new power plant? How youth navigate socioscientific issues. Journal of Research in Science Teaching, 49(5), 541-567.

Medin, D. L., \& Bang, M. (2014). Who's asking? Native science, western science, and science education. Cambridge, MA: The MIT Press.

Penuel, W. R., \& Fishman, B. J. (2012). Large-scale science education intervention research we can use. Journal of Research in Science Teaching, 49(3), 281-304.
Penuel, W. R., Fishman, B. J., Cheng, B. H., \& Sabelli, N. (2011). Organizing research and development at the intersection of learning, implementation, and design. Educational Researcher, 40(7), 331-337.

Stille, S. (2012). Re/making the ground on which they stand: Making a school garden with culturally and linguistically diverse students. Bilingual Basics: TESOL Newsletter, 13(1).

Stille, S. (2013). Making an edible school garden with multilingual children: Engaging linguistic, cultural, and community resources. In S.V. Chappell \& C.J. Faltis, C. J. (Eds.). The arts and emergent bilingual youth: Building critical, creative programs in school and community contexts. New York: Taylor and Francis.

Toohey, K., \& Dagenais, D. (2015). Videomaking as sociomaterial assemblage. Language and Education, 29(4), 302-316. doi:10.1080/09500 782.2015.1006643

Toohey, K., Dagenais, D., Fodor, A., Hof, L., Nuñez-Mendez, O., Schulze, E., et al. (2015). "That sounds so cooool": Entanglements of children, digital tools and literacy practices. TESOL Quarterly, 49(3), 461-485. doi:10.1002/ tesq.236 


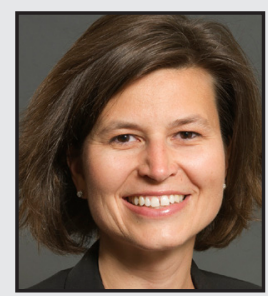

Sara Hagenah is an Assistant Professor of Science Education in the Department of Curriculum, Instruction, and Foundational Studies at Boise State University. Her research is deeply engaged with informal and formal school-community partnerships and aims to collaboratively advance ambitious and equitable science teaching and learning. She has expertise in designing curriculum based on high leverage science teaching practices. She designs and leads job-embedded professional development that focuses on rigorous and responsive science teaching and learning opportunities. Sara received her $\mathrm{PhD}$ in Curriculum and Instruction: Science Education from the University of Washington.

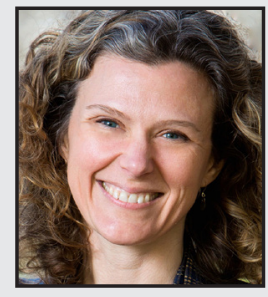

Jessica Thompson is an Associate Professor in Curriculum \& Instruction at the University of Washington and has partnered with Highline Public Schools for 10 years. Her research focuses on building Local Improvement Networks that support ambitious and equitable teaching practice with novice and experienced science teachers, science and English Learner (EL) coaches, principals, and district leadership. She has authored several articles around ambitious and equitable teaching, teacher learning, and tools and routines that support the development of teaching. She has expertise in facilitating and studying teacher learning of ambitious science teaching practices at the elementary and secondary level, as well as expertise in the methods of improvement science. 